\title{
Ciliary Neurotrophic Factor Controls Progenitor Migration during Remyelination in the Adult Rodent Brain
}

\author{
Julien Vernerey, ${ }^{1,2}$ Magali Macchi, ${ }^{1,2}$ Karine Magalon, ${ }^{1,2}$ Myriam Cayre, ${ }^{1,2}$ and Pascale Durbec ${ }^{1,2}$ \\ ${ }^{1}$ Aix-Marseille Université, and ${ }^{2}$ Centre National de la Recherche Scientifique, Institut de Biologie du Développement de Marseille de Luminy, Unité Mixte \\ de Recherche 7288, 13288 Marseille, France
}

Ciliary neurotrophic factor (CNTF) has been shown to be expressed after brain lesions and in particular after demyelination. Here, we addressed the role of this cytokine in the regulation of neural progenitor migration in the adult rodent brain. Using an acute model of demyelination, we show that CNTF is strongly re-expressed after lesion and is involved in the postlesional mobilization of endogenous progenitors that participate in the myelin regenerative process. We show that CNTF controls the migration of subventricular zone (SVZ)-derived neural progenitors toward the demyelinated corpus callosum. Furthermore, an ectopic source of CNTF in adult healthy brains changes SVZ-derived neural progenitors' migratory behavior that migrate toward the source by activation of the Janus kinase/ signal transducer and activator of transcription 3 (JAK/STAT3) pathway. Using various in vitro assays (Boyden chambers, explants, and video time-lapse imaging), we demonstrate that CNTF controls the directed migration of SVZ-derived progenitors and oligodendrocyte precursors. Altogether, these results demonstrate that in addition to its neuroprotective activity and its role in progenitor survival and maturation, CNTF acts as a chemoattractant and participates in the recruitment of endogenous progenitors during myelin repair.

\section{Introduction}

Ciliary neurotrophic factor (CNTF) is a neurotrophic cytokine belonging to the interleukin-6 (IL6) family. Initially characterized as a survival factor for neurons (Adler et al., 1979), CNTF was then shown to support other effects (Sendtner et al., 1994) such as the regulation of subventricular zone (SVZ) cell stemness and self-renewal in embryonic mice (Koblar et al., 1998; Shimazaki et al., 2001; Gregg and Weiss, 2005) and of adult neurogenesis (Emsley and Hagg, 2003; Yang et al., 2008). Moreover, fragmentary data suggest that CNTF could also regulate migratory processes (Emsley and Hagg, 2003; Magni et al., 2007; Ichiki et al., 2008; Xu et al., 2009; Yang et al., 2010). Interestingly, CNTF expression can be increased by injury (Sriram et al., 2004; Bauer et al., 2007), notably by astrocytes (Albrecht et al., 2003) in demyelinating diseases (Emery et al., 2006). The implication of CNTF in multiple sclerosis (MS) has been suggested by work showing CNTF and CNTF-receptor complex upregulation in the motor cortex of MS patients (Dutta et al., 2007), and by the correlation between cntf-null mutation and patients with early onset of the disease (Giess et al., 2002). In CNTF-deficient mice, induction of experimental autoimmune encephalomyelitis (EAE)

\footnotetext{
Received May 29, 2012; revised Dec. 3, 2012; accepted Dec. 16, 2012.

Author contributions: M.C. and P.D. designed research; J.V., M.M., K.M., and M.C. performed research; J.V., M.M., K.M., M.C., and P.D. analyzed data; J.V. and P.D. wrote the paper.

This work was funded by Centre National de la Recherche Scientifique, Aix Marseille University, and the Agence Nationale de la Recherche. V.J. was supported by the French Ministry of Research and further by ARC. We thank Maina's laboratory for stimulating discussions; and Lydia Kerkerian and Sylvian Bauer for critical reading of the manuscript.

The authors declare no financial conflicts of interest.

Correspondence should be addressed to Dr. Pascale Durbec, IBDML-UMR 7288, Case 907, Parc Scientifique de Luminy, 13288 Marseille Cedex 09, France. E-mail: pascale.durbec@univ-amu.fr.

DOI:10.1523/JNEUROSCI.2579-12.2013

Copyright $\odot 2013$ the authors $\quad 0270-6474 / 13 / 333240-11 \$ 15.00 / 0$
}

resulted in axonal damage, reduction of oligodendrocyte progenitor cell (OPC) proliferation and increased cell death (Linker et al., 2002). A modulatory role for CNTF in neuroinflammation has been further suggested in experimental autoimmune EAE model with decreased demyelination after intravenous injection of CNTFproducing cells (Lu et al., 2009). Finally, the link between CNTF and myelin repair has been clearly suggested because of its role in oligodendroglial lineage cell proliferation (Barres et al., 1996), survival (Barres et al., 1993; Linker et al., 2002; Lu et al., 2009), and maturation (Stankoff et al., 2002).

Replacement of myelinating oligodendrocytes by endogenous progenitors has been demonstrated to occur following oligodendrocyte death in mouse via the recruitment of SVZ-derived progenitors (Nait-Oumesmar et al., 1999; Magalon et al., 2007; Jablonska et al., 2010) and parenchymal OPCs (Franklin and ffrench-Constant, 2008). The adult brain, which is characterized by limited cell migration, activates a postlesional plasticity whereby nonpermissive areas become permissive, leading to a shift in the migration mode of neural progenitors (Connor et al., 2011). Numerous signals are involved in this active migration of progenitors into the damaged area ranging from developmental signals re-expressed at the lesion site (Aguirre et al., 2007; Williams et al., 2007; Gonzalez-Perez et al., 2009; Courtès et al., 2011) to neuroinflammation-induced cytokines (Connor et al., 2011). Since CNTF has been shown to be upregulated after demyelination and could potentially regulate migratory processes, we addressed its possible role in progenitor recruitment at the lesion. Our results indicate that CNTF participates in the control of SVZ progenitor cell migration in vivo. Using in vitro assays, we show that CNTF acts as a chemoattractant on both neuronal and glial progenitors. Altogether, these results indicate that CNTF, in addition to its neuroprotective action and its role on cell survival 
and maturation, could act as a chemoattractant during myelin repair processes.

\section{Materials and Methods}

Animals. All experimental and surgical protocols were performed according to the guidelines established by the French Ministry of Agriculture (Animal Rights Division). The architecture and functioning rules of our animal house, as well as our experimental procedures have been approved by the "Direction Départementale des Services Vétérinaires" (identification number E-13-055-21).

SVZ-derived cells tracing. One day before surgery, animals received four intraperitoneal injections of the thymidine analog BrdU (100 mg/ $\mathrm{kg}$; Sigma) at $2 \mathrm{~h}$ intervals. Cells integrating BrdU at the time of injections are restricted to the SVZ and rostral migratory stream (RMS). Therefore, $4 \mathrm{~d}$ after surgery, labeled cells detected in lesion area or around the graft are assumed to originate from the SVZ or the RMS (Cantarella et al., 2008). BrdU ${ }^{+}$-recruited cells were phenotyped as follows: in the focal demyelination and CNTF neutralizing antibody infusion model and in the grafting model, $\mathrm{BrdU}^{+}$cell types were determined both in the corpus callosum (CC), between the SVZ-RMS system and the lesion site or the grafting site (see Fig. $2 B$, quantification area). All observations were performed using AxioImager Z1 with Apotome system (Zeiss) (magnification $20 \times$ ) and analyzed using Axiovision software.

Focal demyelination and CNTF neutralizing antibody infusion. Lysolecithin (LPC)-induced focal demyelination was performed as previously described (Decker et al., 2002) with minor modifications. Male C57BL/6 mice (8 weeks of age; 23-25 g; Charles River) were anesthetized (ketamine, $100 \mathrm{mg} / \mathrm{kg}$; xylazine, $10 \mathrm{mg} / \mathrm{kg}$ ) and unilaterally injected with 0.5 $\mu$ l of a solution of $1 \%$ LPC (Sigma) in $0.9 \% \mathrm{NaCl}$ into the CC at stereotaxic coordinates from bregma: $1.5 \mathrm{~mm}$ rostral, $1 \mathrm{~mm}$ lateral, $2 \mathrm{~mm}$ deep from the dura mater. Two and seven days after injection, structures surrounding the lesion (CC together with adjacent parts of cortex and striatum for LPC-induced demyelination) and their counterparts in the contralateral hemisphere, were dissected on 1-mm-thick coronal slices in cold HBSS and processed for Western blot analysis. For blocking experiments, we used CNTF neutralizing antibody (AB-557-NA, goat IgG; $\mathrm{R} \& \mathrm{D}$ Systems), which has an $\mathrm{ED}_{50}$ value of $7-15 \mu \mathrm{g} / \mathrm{ml}$ in the presence of $1 \mathrm{ng} / \mathrm{ml}$ recombinant rat CNTF in the survival assay of embryonic chick dorsal root ganglia neurons (as described by the manufacturer). Using semiquantitative Western blot analysis including a range of recombinant CNTF for calibration (from 7.5 to $0.5 \mathrm{ng} / \mu \mathrm{l}$ ), we calculated that the CNTF concentrations were $2.03 \pm 0.02$ and $0.96 \pm 0.10 \mathrm{ng} / \mu \mathrm{l}$, respectively, on the ipsilateral and contralateral sides of the CC $4 \mathrm{~d}$ after LPC injection. This increase by $111 \%$ of CNTF concentration at the ipsilateral side corresponds to an increase of $1.07 \pm 0.10 \mathrm{ng} / \mu \mathrm{l} \mathrm{CNTF}$. According to the manufacturer, we neutralized CNTF overexpression at the lesion site by injecting antibody at $11.1 \mu \mathrm{g} / \mu \mathrm{l}$ in a single injection $(1 \mu \mathrm{l})$, concomitantly to LPC. Purified goat IgG (Jackson ImmunoResearch) was used as a control. Four days later, animals were anesthetized and transcardially perfused with ice-cold $4 \%$ paraformaldehyde (PFA). Brains were post-fixed for $20 \mathrm{~min}$ in $4 \%$ PFA; cryoprotected overnight in $15 \%$ sucrose, $0.1 \mathrm{M}$ phosphate buffer (PB); embedded in 15\% sucrose, $7.5 \%$ gelatin, $0.1 \mathrm{M} \mathrm{PB}$; and cut on a cryostat (Leica) in six series of sagittal sections (15 $\mu \mathrm{m}$ thick).

Transplantation and analysis of grafted cells. Male C57BL/6 mice ( 8 weeks of age; $23-25 \mathrm{~g}$; Charles River) were anesthetized and unilaterally injected with CNTF-secreting or control HEK cells $(50,000$ cells in $0.5 \mu l$ of HBSS) into CC at the following stereotaxic coordinates from bregma: $1 \mathrm{~mm}$ rostral, $1 \mathrm{~mm}$ lateral, $2 \mathrm{~mm}$ deep from the dura mater. Mice were immunosuppressed by daily injection of $20 \mathrm{mg} / \mathrm{kg}$ cyclosporine A (Sandimmun, Novartis), killed at $4 \mathrm{~d}$ postgrafting, and processed for histology. Analysis of RMS architecture $4 \mathrm{~d}$ postgrafting was performed using Axio Imager Z1 with the Apotome system (Zeiss) (magnification 20X). The length of doublecortin (DCX) labeling interruptions (gaps) was measured using the Axiovision software within the first $800 \mu \mathrm{m}$ of the RMS starting from the SVZ. We quantified on the same pictures the number of neuronal progenitors exiting the RMS toward the CC, within a $100-\mu \mathrm{m}-$ wide by $800-\mu \mathrm{m}$-long area just above the RMS.

Western blot analysis. Tissues were homogenized and lysed on ice for $30 \mathrm{~min}$ in lysis buffer (50 mm Tris- $\mathrm{HCl} \mathrm{pH}$ 7.5, $150 \mathrm{~mm} \mathrm{NaCl}, 1 \mathrm{~mm}$
EDTA, 1\% Triton X 100, 1 mm PMSF, and anti-proteases; $100 \mathrm{mg}$ of tissue $/ \mathrm{ml}$ ) and supernatant collected after centrifugation (15 min, $15,000 \times g, 4^{\circ} \mathrm{C}$ ). Protein concentrations were determined using a Pierce BCA kit (ThermoFisher Scientific), and proteins (40 $\mu \mathrm{g} /$ well) were resolved by $4-12 \%$ NuPAGE Novex gels (Life Technologies); transferred onto a PVDF membrane; probed overnight with mouse anti-CNTF (1: 500; MAB338; Millipore), goat anti-CNTFR $\alpha$ (SC-1914; 1:500; Santa Cruz Biotechnology), rabbit anti-phospho-signal transducer and activator of transcription 3 (p-STAT3; 1:2000; catalog \#9145; Cell Signaling Technology), mouse anti-STAT3 (1:1000; catalog \#9139; Cell Signaling Technology), or mouse anti- $\alpha$-tubulin (1:30,000; T9026; Sigma); then incubated with horseradish peroxidase-conjugated antibodies (1:1500; Jackson ImmunoResearch) and Rapidstep ECL reagent (catalog \#345818; Calbiochem). Chemiluminescence was registered under the ECL Imager Chemi-Smart system (Fisher Bioblock Scientific). Semiquantitative analysis of CNTF expression was performed using Bio-1D Advanced Software (Vilmer Lourmat) using $\alpha$-tubulin as a reference.

Cell culture. Unless specified, all culture reagents were purchased from Invitrogen.

HEK cell culture and transfection. CNTF-internal ribosome entry site 2-mono red fluorescent protein ( $\mathrm{mRFP}$ ) or mRFP alone sequences were cloned into an empty pCMV vector (Clontech). Constructs were stably transfected in HEK 293 cells (CRL-1573; ATCC), selected with Geneticin (450 $\mu \mathrm{g} / \mathrm{ml}$; Life Technologies) and maintained in DMEM, 10\% fetal bovine serum (FBS), MEM sodium pyruvate (1 mM), and 1\% penicillin/ streptomycin. CNTF secretion was checked by Western blot using cell culture conditioned medium (data not shown).

Primary culture of SVZ-derived progenitors grown as neurospheres. SVZderived neurospheres were generated as described previously by Durbec and Rougon (2001) from P1-P3 CD1 newborn mice, in defined medium (DMEM/F12, 3:1), insulin (5 $\mathrm{g} / \mathrm{ml}$; Sigma), apo-transferrin (100 $\mu \mathrm{g} /$ $\mathrm{ml}$; Sigma), putrescine (100 $\mu \mathrm{M}$; Sigma), progesterone (20 nм; Sigma), selenium (30 nм; Sigma), and penicillin-streptomycin (100 IU/ml and $100 \mu \mathrm{g} / \mathrm{ml}$, respectively) supplemented with $2 \%$ B27, EGF, and bFGF (20 $\mathrm{ng} / \mathrm{ml}$; Peprotech). Cells were grown for 1 week in a $5 \% \mathrm{CO}_{2}$ atmosphere at $37^{\circ} \mathrm{C}$. For CNTF stimulation, neurospheres were washed and starved for $5 \mathrm{~h}$ in DMEM/F12 (3:1) medium, and stimulated for $10 \mathrm{~min}$ at $37^{\circ} \mathrm{C}$ with CNTF (100 ng/ml; Sigma). Stimulation was stopped by placing the cells on ice and washing them with ice-cold PBS. Finally, spheres were lysed and processed for Western blot analysis to check for p-STAT3 and STAT3 expression.

Primary culture of SVZ explants. SVZ explants were obtained as described previously by Chazal et al. (2000) from P1-P3 CD1 newborn mice. SVZ explants were mixed in HBSS and Matrigel (BD Biosciences) in a 1:2 ratio and disposed equally distant to a Affi-Gel Blue Gel bead (Bio-Rad) soaked with CNTF (10 $\mu \mathrm{g} / \mathrm{ml}$; Sigma) or PBS as a control, in neurosphere-defined medium (see above) supplemented with B27. Explants were analyzed $24 \mathrm{~h}$ later using an Axio Observer Z1 microscope (Zeiss). The length of migratory chains was measured proximal and distal to the bead in three independent measurements (see Fig. 3C).

Purified OPCs culture. Purified rat OPCs were prepared as described by Chen et al. (2007). Briefly, cortices from P0 Sprague Dawley rats were removed; cut into small pieces; dissociated using trypsin-EDTA $0.05 \%$ and DNase I ( $10 \mu \mathrm{g} / \mathrm{ml}$; Sigma), and fire polished Pasteur pipettes; and platted on poly-D-lysine $(10 \mu \mathrm{g} / \mathrm{ml}$; Sigma) in DMEM, FBS $(20 \%$; Thermo Fisher Scientific), MEM sodium pyruvate (1 mM) and penicillinstreptomycin (100 IU/ml and $100 \mu \mathrm{g} / \mathrm{ml}$, respectively). Seven days later, OPCs were isolated using a differential shaking protocol, providing single cells used for Boyden chamber assays and aggregates that we used for video time-lapse experiments.

For CNTF stimulation, cells were platted on poly-L-lysine-coated glass slides, starved for $5 \mathrm{~h}$ in DMEM/F12 (3:1) medium, and stimulated for 10 min with CNTF (100 ng/ml; Sigma). Stimulation was stopped the same way. Finally, slides were processed for immunocytochemistry and checked for p-STAT3 expression. Observation and pictures were done using Axio Imager $\mathrm{Z} 1$ with the Apotome system (Zeiss). For each experiment $(n=4)$, pictures were collected in a unique session using a PlanApochromat $20 \times / 0.8$ objective (Zeiss), and the exposure time was constant and set up to avoid saturation for all the photographs. Fluores- 
cence intensity was calculated for each cell in the four experiments (2927 cells for control; 2413 in the presence of CNTF) using ImageJ software (National Institutes of Health).

Boyden chamber assay. Dissociated neurospheres or purified OPCs were resuspended at $2.10^{6}$ cells $/ \mathrm{ml}$ in neurosphere-defined medium supplemented with B27 and Cytosine $\beta$-D-arabinofuranoside ( $5 \mu \mathrm{M}$; AraC; Sigma), and OPC-defined medium (DMEM), insulin ( $5 \mu \mathrm{g} / \mathrm{ml}$; Sigma), FBS (0.5\%; Thermo Fisher Scientific), apo-transferrin $(100 \mu \mathrm{g} / \mathrm{ml}$; Sigma), putrescine (100 $\mu$; Sigma), progesterone (20 nM; Sigma), selenium (30 nм; Sigma), D-biotin (10 ng/ml; Sigma), AraC (5 $\mu \mathrm{m}$; Sigma), respectively. Neurosphere and OPC migration assays were performed, respectively, on poly-DL-ornithine-coated ( $3 \mu \mathrm{g} / \mathrm{ml}$; Sigma) and poly-Llysine-coated (10 $\mu \mathrm{g} / \mathrm{ml}$; Sigma) transwell polycarbonate membranes with $8 \mu \mathrm{m}$ pores (Corning). Assays were performed as follows: growth factors, including stromal cell-derived factor-1 (SDF1; $50 \mathrm{nM}$; Millipore), platelet-derived growth factor (PDGF-AA; $5 \mathrm{ng} / \mathrm{ml}$; Peprotech), and $\operatorname{CNTF}(1,10$, and $100 \mathrm{ng} / \mathrm{ml}$; Sigma) were diluted in the corresponding medium and added to the lower chamber. One hundred microliters of cell-containing solutions (including growth factor as indicated) was then placed in the upper chamber. Twenty-four hours later, membranes were fixed for $20 \mathrm{~min}$ in 4\% PFA and mounted in Vectashield+DAPI (AbCys). Concerning OPCs, membranes were also labeled against Olig2. Neurosphere and OPC migration assay data results from 10 and 8 independent experiments, respectively. Cells that had migrated through the pores were counted in 10-15 adjacent fields per membrane, and data (number of cells per field) were expressed relative to control.

Video time lapse. Purified OPCs aggregates were placed on a poly-Llysine-coated dish, and $1 \mathrm{~h}$ later (i.e., time for aggregates to adhere to the dish) aggregates were embedded with 10\% Matrigel diluted in OPCdefined medium in the presence of $10 \mu \mathrm{M}$ AraC, and a bead soaked with CNTF $(1 \mu \mathrm{g} / \mathrm{ml})$ was disposed close to them. Recording started $1 \mathrm{~h}$ later (i.e., to be sure to record healthy aggregates) for $10 \mathrm{~h}$ (20 images/h, $5 \times$ magnification) using an Axio Observer $\mathrm{Z} 1$ microscope (Zeiss) equipped with a thermostatic chamber $\left(37^{\circ} \mathrm{C}, 5 \% \mathrm{CO}_{2}\right)$. Efficient migration length, mean migration speed, and tortuosity (ratio of the total length of a curve followed by a cell to the distance between its two ends) were calculated using the manual tracking plugins added to the ImageJ software.

Immunohistochemistry. We used the following antibodies: rat antiBrdU (1:500; Clone BU1/75; AbCys) and mouse anti-BrdU (Clone Bu20a; 1:100; Dako) to trace SVZ-derived cells; mouse anti-mammalian achaete-scute homolog1 (Mash1; 556604; 1:100; BD PharMingen) for SVZ-derived transitory amplifying cells; goat anti-DCX (SC-8066; 1:250; Santa Cruz Biotechnology) for SVZ-derived neuronal precursors; mouse anti-glial fibrillary acidic protein (GFAP; 1:1000; Clone G-A-5; Sigma) for astrocytes; rabbit anti-Olig2 (AB9610; 1:1000, Millipore) for oligodendrocyte lineage cells; rabbit anti-phosphohistone 3 (1:250; PH3; 06570; Millipore) and mouse anti-Ki67 (1:500; catalog \#556003; BD PharMingen) for mitotic cells; and rabbit anti-caspase 3 (1:200; catalog \#9661; Cell Signaling Technology) for apoptotic cells. To study CNTFR $\alpha /$ LIFR $\beta /$ GP130 downstream pathways, we used the following: rabbit anti-p-STAT3 (1:100; Tyr705; catalog \#9145; Cell Signaling Technology) for Janus kinase (JAK)/STAT3 activation, rabbit anti-phospho Akt (Ser473; 1:50; catalog \#4060; Cell Signaling Technology) for phosphatidylinositol 3-kinase/v-akt murine thymoma viral oncogene homolog 1 (PI3K/Akt) activation and rabbit anti-phospho ERK1/2 (Thr202/Tyr204; 4376; 1:100; Cell Signaling Technology) for mitogenactivated protein kinases/extracellular signal-regulated kinases (MAPK/ ERK) activation. Secondary antibodies coupled with Alexa Fluor 488, Alexa Fluor 555, or Alexa Fluor 649 (Life Technologies/Invitrogen) were used. For BrdU immunostaining, sections were first incubated for $20 \mathrm{~min}$ in $2 \mathrm{~N} \mathrm{HCl}$, PBS $0.3 \%$, Triton $\mathrm{X}-100$ at $37^{\circ} \mathrm{C}$, and then for $20 \mathrm{~min}$ in $0.1 \mathrm{M}$ borate buffer, $\mathrm{pH}$ 8.5. Finally, sections were counterstained with Hoechst 33342 (1:1000; Sigma).

Immunocytochemistry. The following antibodies were used: rabbit anti-Olig2 and rat anti-PDGF receptor $\alpha$ (1:500; CBL1366; Millipore) for OPCs, rabbit anti-p-STAT3 as a readout for CNTFR $\alpha /$ LIFR $\beta /$ GP130 downstream pathway activation, and rabbit anti-PH3 for mitotic cells of SVZ explant experiments. Secondary antibodies were the same as for immunohistochemistry. For Olig2 immunostaining, sections were first incubated for $15 \mathrm{~min}$ at $37^{\circ} \mathrm{C}$ in $10 \mathrm{~mm}$ sodium citrate buffer, $\mathrm{pH} 6$.

Statistical analysis. All the presented values are means \pm SEM. For related and independent two-group comparisons, the data were statistically processed with the nonparametric Wilcoxon signed rank test and Wilcoxon-Mann-Whitney test, respectively. Multiple group comparisons were performed using ANOVA with general scores followed by post hoc analysis (Kruskal-Wallis test). $p<0.05$ was considered significant, and $p<0.01$ highly significant. All measurements and subsequent evaluations were performed blind to the experimental group to which the animals belonged.

\section{Results}

CNTF upregulation after acute LPC demyelination of the corpus controls SVZ-derived progenitor migration

First, we analyzed the modulation of CNTF expression after the induction of focal demyelination by LPC injection in the CC (Fig. $1 B)$. In this model, the phases of demyelination and remyelination are temporally distinct; demyelination occurs within $2 \mathrm{~d}$ after LPC injection. Endogenous progenitor mobilization then occurs, and cells are clearly visible within the lesion at $7 \mathrm{~d}$ postinjection (dpi). Remyelination is complete 2 weeks after injection. Using semiquantitative Western blot analysis, we observed a significant upregulation of CNTF in the perilesional structures in the ipsilateral compared with the contralateral side 2 dpi $(284 \pm$ $65 \% ; p=0.045$; Fig. 1A). CNTF expression was reinforced at 7 dpi $(779 \pm 158 \%$ of the control value at $2 \mathrm{dpi} ; p=0.028$; Fig. $1 \mathrm{~A})$.

To determine whether lesion-induced CNTF secretion could influence SVZ-derived progenitor mobilization, and more specifically their migration toward the lesion, we injected CNTF neutralizing antibody (Yang et al., 2008), or IgG for control, concomitantly with LPC into the CC of adult mice. SVZ-derived progenitors were traced using BrdU administration $1 \mathrm{~d}$ before lesion induction (see Materials and Methods). Four days after induction, the lesion was clearly visible by the absence of myelin basic protein (MBP) labeling and a strong densification of DAPI at the injection point (Fig. 1C). The lesion size was similar in both groups $\left(4.5 \times 10^{-3} \pm 6 \times 10^{-4} \mathrm{~mm}^{3}\right.$ in IgG mice vs $3.8 \times 10^{-3} \pm$ $4 \times 10^{-4} \mathrm{~mm}^{3}$ in anti-CNTF-injected mice; $\left.p=0.49\right)$. We found a strong decrease in the recruitment within the lesion in anti-CNTFinjected mice, with $45 \%$ fewer $\mathrm{BrdU}^{+}$cells compared with controls ( $p=0.027$; Fig. $1 D-F$; Table 1A). Importantly, CNTF blockade did not modify the mitotic activity or the rate of cell death of cells within the lesion and more specifically of SVZ-derived progenitors recruited to the lesion (Table 1, site A). Cell proliferation in the SVZ was identical in both groups (Table 1, site C). These results strongly suggest that postlesional CNTF upregulation participates in the recruitment process by enhancing SVZ-derived progenitor migration toward the focal demyelinated lesion.

To characterize SVZ-derived progenitors, early ectopic $\mathrm{BrdU}^{+}$cells present in the CC between the SVZ-RMS and the lesion site were phenotyped $4 \mathrm{~d}$ after lesion induction (see Table 3 , site A). CNTF blocking antibody did not interfere significantly with the percentage of Olig ${ }^{+}$or $\mathrm{Mash}^{+}{ }^{+}$cells among BrdU ${ }^{+}$ cells. Interestingly, in the presence of CNTF blocking antibody the number of $\mathrm{DCX}^{+} \mathrm{BrdU}^{+}$cells was significantly increased by $16 \%$ compared with control, while the number of $\mathrm{GFAP}^{+}$ $\mathrm{BrdU}^{+}$cells was decreased by $54 \%$ (Table 3 , site A). These results suggest that $\mathrm{CNTF}$ either favors the recruitment of specific cell types or changes the fate of mobilized cells as they exit the SVZRMS system.

Since lesion-induced CNTF secretion could also influence OPC mobilization, we quantified the absolute number of Olig $2^{+}$ $\mathrm{BrdU}^{-}$cells around the lesion site $4 \mathrm{~d}$ after LPC injection. Olig2 ${ }^{+}$ 

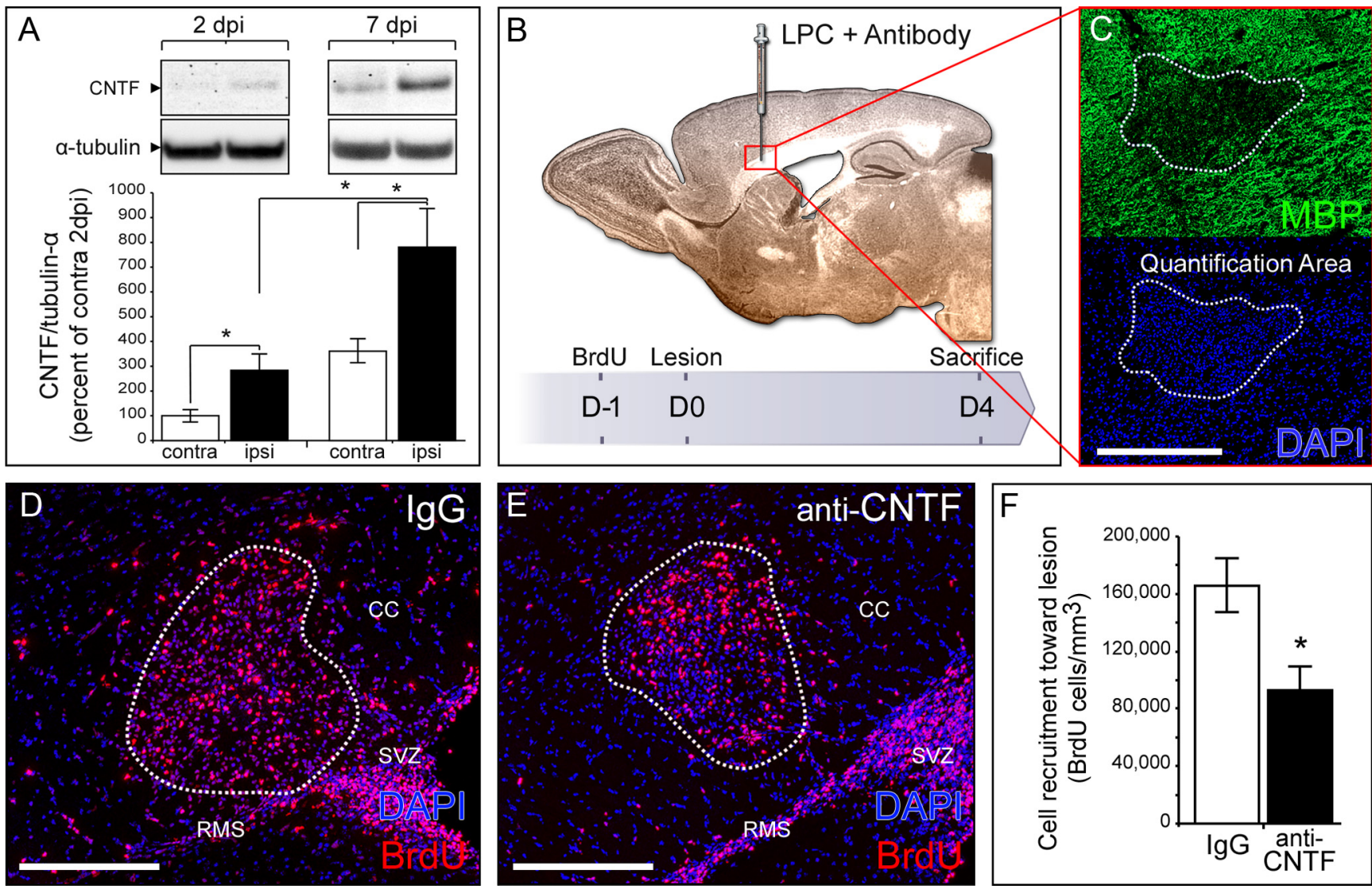

Figure 1. CNTF is upregulated after demyelination in the CC and participates in SVZ-derived cell recruitment to the lesion site. $A$, Western blot and semiquantitative analysis of CNTF expression in perilesional areas 2 and $7 \mathrm{~d}$ after LPC-induced demyelination. CNTF expression was normalized to $\alpha$-tubulin and expressed as the percentage of the contralateral (unlesioned) side 2 dpi (protein samples from five lesioned adult mice for each time point). $\boldsymbol{B}$, Illustration of the coinjection of LPC and CNTF neutralizing antibody in the CC and representation of the experimental design for histological analysis. $\boldsymbol{C}$, Four days postinjection, the demyelinated area is revealed by the loss of MBP immunostaining and the densification of DAPI (delineated by a white dashed line). $\boldsymbol{D}, \boldsymbol{E}$ BrdU labeling showing SVZ-derived cell recruitment toward the demyelinated area. $F$, Quantification of BrdU ${ }^{+}$cells within thelesion site showing a significant decrease in cell recruitmentin micetreated with CNTF-neutralizing antibody compared with lgG-treated mice. Data from nine lgG-treated mice, 10 anti-CNTF-injected mice in two independent experiments. All pictures are from brain sagittal sections. Scale bars, $200 \mu \mathrm{m}$.

Table 1. Cell proliferation and survival $4 \mathrm{~d}$ after CNTF neutralizing antibody and LPC injection in corpus callosum

\begin{tabular}{|c|c|c|c|c|}
\hline Site & Cells & $\lg G$ & Anti-CNTF & $p$ value \\
\hline \multirow[t]{5}{*}{ A: at the lesion } & $\mathrm{BrdU}^{+}$cells $/ \mathrm{mm}^{3}$ & $166,158 \pm 18,691$ & $92,639 \pm 16,921$ & 0.022 \\
\hline & $\% \mathrm{PH}^{+} / \mathrm{BrdU}^{+}$cells & $1.40 \pm 0.49$ & $1.41 \pm 0.38 \%$ & 0.96 \\
\hline & $\%$ Casp $^{+} / \mathrm{BrdU}^{+}$cells & $0.36 \pm 0.08$ & $0.54 \pm 0.24 \%$ & 0.87 \\
\hline & $\mathrm{PH}^{+}$cells $/ \mathrm{mm}^{3}$ & $37,692 \pm 5,842$ & $31,988 \pm 4,811$ & 0.35 \\
\hline & Casp3 $^{+}$cells $/ \mathrm{mm}^{3}$ & $3353 \pm 346$ & $3,818 \pm 734$ & 0.89 \\
\hline \multirow[t]{3}{*}{ B: around the lesion } & Olig2 ${ }^{+} \mathrm{BrdU}^{-}$cells $/ \mathrm{mm}^{3}$ & $20,814.9 \pm 1,171.4$ & $9,890.1 \pm 1,568.5$ & 0.033 \\
\hline & $\%{\mathrm{Ki} 67^{+}}^{+}$Olig2 ${ }^{+} \mathrm{BrdU}^{-}$cells & $11.9 \pm 0.7 \%$ & $2.5 \pm 2.2 \%$ & 0.027 \\
\hline & $\% \mathrm{Ki} 7^{+} / 0 \mathrm{lig} 2^{+} \mathrm{BrdU}^{+}$cells & $3.13 \pm 3.1 \%$ & $2.22 \pm 2.2 \%$ & 1 \\
\hline C: SVZ niche & $\mathrm{PH} 3^{+}$cells $/ \mathrm{mm}^{3}$ & $38,814.7 \pm 3,087.8$ & $39,073.7 \pm 5,161.1$ & 0.84 \\
\hline
\end{tabular}

For site A, proliferation and survival indexes were determined using PH3 and Casp3 markers, respectively, among BrdU ${ }^{+}$at the lesion site (see quantification area in Fig. 10). Overall proliferation and survival indexes were determined by counting the number of $\mathrm{PH}_{3}{ }^{+}$cells $/ \mathrm{mm}^{3}$ and Casp ${ }^{+}$cells $/ \mathrm{mm}^{3}$ at the lesion site. For site B, proliferation of OPCs was determined using Ki67 marker among BrdU ${ }^{+}, 0$ lig2 ${ }^{+}$, and BrdU ${ }^{-}$Olig2 ${ }^{+}$cells. 0 lig2 ${ }^{+}$cells were quantified within a $50-\mu \mathrm{m}$-wide corridor surrounding the lesion site. For site C, cell proliferation was estimated within the SVZ by counting the number of PH3 ${ }^{+}$cells/mm ${ }^{3}$. Data are from nine IgG-treated mice and 10 anti-CNTF-injected mice in two independent experiments.

$\mathrm{BrdU}^{-}$cells include mainly parenchymal oligodendrocyte lineage cells and a fraction of SVZ-derived OPCs that escaped from BrdU labeling. We observed a significant decrease in the number of Olig2 ${ }^{+} \mathrm{BrdU}^{-}$cells in the presence of CNTF blocking antibody compared with control (Table 1, site B). Furthermore, CNTF neutralization, significantly decreased the proliferation capacity of this population (Table 1, site B). By contrast, the proliferation of Olig2 ${ }^{+} \mathrm{BrdU}^{+}$cells was not affected by CNTF neutralization (Table 1, site B). These results suggest that CNTF specifically favors parenchymal OPC proliferation.
Overall, these results suggest that postlesional CNTF upregulation participates in the endogenous progenitor cell mobilization process, more specifically by enhancing SVZ-derived progenitor migration toward the lesion and parenchymal OPC proliferation.

CNTF ectopic expression in the CC is sufficient to trigger SVZ-derived directed cell migration

To directly evaluate the influence of CNTF on the migratory behavior of SVZ-derived cells, we grafted mRFP HEK cells secret- 
ing or not secreting CNTF into the CC of healthy mice (Fig. $2 A, B)$. We quantified SVZ-derived cells present in the CC adjacent to the graft $4 \mathrm{~d}$ after surgery using BrdU tracing as mentioned above (Fig. 2B). We found a $77 \%$ increase in the number of $\mathrm{BrdU}^{+}$cells present in the CC of CNTF-secreting HEK-grafted mice compared with controls ( $p=0.028$; Fig. $2 C-E$; Table 2 , site A). No significant differences in cell proliferation or survival were observed in the CC and, more importantly, among SVZ-derived cells in this structure (Table 2, site A). Cell proliferation in the SVZ was not significantly different between the groups (Table 2, site C). Together, these results seem to indicate that CNTF overexpression is able to interfere with the normal migratory behavior of SVZ-derived progenitors. Interestingly, we found that the overall cytoarchitecture of the RMS was affected in the presence of CNTF-secreting cells (Fig. $2 F-H$ ). While in the control condition, DCX labeling indicated a continuous RMS, we found longer RMS interruptions (gaps) in the presence of CNTF-secreting HEK $(52 \pm 21 \mu \mathrm{m} /$ gap in control HEK vs $110 \pm 12 \mu \mathrm{m} /$ gap in CNTF-secreting HEK condition; $p=0.043$; Fig. $2 H$ ). Furthermore, the number of ectopic $\mathrm{DCX}^{+}$cells in the CC just above the RMS was significantly increased by $125 \%$ in the presence of a CNTF ectopic source ( $p=0.028$; Fig. $2 I-K)$. These results indicate that the disruption observed in the RMS is correlated to an increased number of $\mathrm{DCX}^{+}$cells in the adjacent corpus callosum and confirmed a disturbance of SVZ-derived cell migratory behavior due to the presence of an ectopic source of CNTF.

To directly link $\mathrm{BrdU}^{+}$cell redistribution to components of the CNTF pathway, double immunostaining was performed $4 \mathrm{~d}$ after surgery (Fig. $2 L-N$ ). Intracellular signaling through CNTF receptors involves three major signal transduction pathways: JAKs/STATs, MAPK/ERK, and PI3K/Akt signaling cascades (Boulton et al., 1994; Heinrich et al., 1998). While no change was observed in the percentage of either $\mathrm{pAkt}^{+}$or pERK1/2 ${ }^{+}$cells among the $\mathrm{BrdU}^{+}$population, a significant increase in the percentage of $\mathrm{BrdU}^{+}$pSTAT3 $^{+}$cells was quantified in the CC of animals grafted with CNTF-secreting cells compared with control (Fig. $2 L-N$ ). These results indicate that the JAK/STAT3 pathway is preferably activated in the SVZ-derived cells responding to CNTF by redistribution in the CC.

Then, we phenotyped ectopic $\mathrm{BrdU}^{+}$cells present in the CC outside the SVZ-RMS system $4 \mathrm{~d}$ after grafting. We observed a small but not significant decrease in the percentage of $\mathrm{DCX}^{+}$cells associated with a nonsignificant increase in $\mathrm{GFAP}^{+}$and Olig2 ${ }^{+}$ populations (Table 3, site B). These results suggest that CNTF ectopic expression does not significantly modify the type and fate of mobilized SVZ-derived cells in the nonpathological condition.

Since we have shown that CNTF influences oligodendrocyte lineage cells after LPC induction (Table 1, site B), we quantified the number of proliferating Olig $2^{+} \mathrm{BrdU}^{-}$cells $4 \mathrm{~d}$ after grafting. We observed a significant increase in the percentage of $\mathrm{Ki}^{+}$ cells among Olig2 ${ }^{+} \mathrm{BrdU}^{-}$cells in the CC of CNTF-secreting cell-grafted animals compared with control (Table 2, site B). Here again, no significant difference was observed in the percentage of $\mathrm{Ki}^{+}{ }^{+}$cells among Olig2 ${ }^{+} \mathrm{BrdU}^{+}$cells (Table 2, site B). This further confirms the role of CNTF in the regulation of parenchymal OPC proliferation in vivo.

Overall, our results show that CNTF ectopic expression in the CC is able to modify the migratory behavior of SVZ-derived cells. This leads to a redistribution of SVZ cell populations to the CC and a specific activation of the JAK/STAT3 signaling pathway. Furthermore, CNTF ectopic expression stimulates parenchymal OPC proliferation in this nonpathological condition.

\section{CNTF exerts a chemoattractant effect on SVZ progenitors in vitro}

We used various in vitro assays to better characterize how CNTF influences SVZ progenitor migration. First, we determined whether SVZ neural progenitors, which are known to express CNTF receptor units (Emsley and Hagg, 2003; Galvão et al., 2008), respond to CNTF. To this end, we used in vitro amplified SVZ cells grown as neurospheres, exposed them to CNTF, and monitored STAT3 phosphorylation (pSTAT3) by Western blot analysis. We observed a sevenfold increase of p-STAT3 in the presence of exogenous CNTF compared with control ( $p=0.049$; Fig. $3 A$ ), indicating that SVZ cells can activate downstream signaling cascade in response to CNTF. We then tested the capacity of CNTF to influence SVZ progenitor migration using dissociated neurospheres on Boyden chamber assays. Exposition of the cells to different ranges of CNTF concentration gradients in the presence of the antimitotic AraC showed maximal migratory effects between 10 and $100 \mathrm{ng} / \mathrm{ml}$ (236 $\pm 67 \%$ and $268 \pm 43 \%$, respectively, compared with control; $p=0.039$ and $p=1 \times 10^{-6}$, respectively; Fig. 3B). The CNTF effect was comparable to that of CXCL12 (SDF1; $50 \mathrm{nM}$ ), which we used here as a positive control (Dziembowska et al., 2005; Carbajal et al., 2010) ( $p=1 \mathrm{E}-06$; Fig. 3B). Interestingly, the number of cells migrating to the lower chamber dramatically dropped to reach control levels when CNTF $(100 \mathrm{ng} / \mathrm{ml})$ was present in both compartments, thus abolishing the gradient (Fig. $3 B$ ). Together, these data suggest that SVZ neural progenitors respond to $\mathrm{CNTF}$ in a gradient-sensing manner and that CNTF acts as a chemoattractant for SVZ precursors.

Next, we investigated whether a localized source of CNTF could influence SVZ neuronal progenitor migration. We cultured freshly dissected SVZ explants in a three-dimensional matrix (Wichterle et al., 1997) together with an agarose bead soaked in CNTF or PBS for control (Fig. 3C). Twenty-four hours after plating, we estimated the chain migration length (distance between the edge of the explants and the migrating front of chains) proximal or distal to the bead in both groups. In these conditions, beads soaked with CNTF were capable of inducing a clear directional migration of SVZ-derived neuronal progenitors, while control beads were ineffective $(p=$ 0.0037; Fig. 3D-F). This effect was not due to cell proliferation since very few migrating cells were proliferating, and no significant difference ( $p=0.125 ; n=4)$ could be observed between proximal $\left(0.15 \pm 0.09 \% \mathrm{PH}^{+}\right.$cells $)$and distal $\left(0.52 \pm 0.14 \% \mathrm{PH} 3^{+}\right.$cells $)$ cells in the presence of a local source of CNTF.

Therefore, CNTF exerts an attractant effect on SVZ-derived neuronal progenitors. On the basis of these results, we conclude that CNTF acts as a directional cue on SVZ cells, influencing cells migrating both individually and cooperatively.

\section{CNTF exerts a chemoattractant effect on OPCs in vitro}

OPCs are the other cell type mobilized after demyelination (Gensert and Goldman, 1997). Significant effects of CNTF on Olig2 ${ }^{+}$cell proliferation were observed in vivo in both lesion and grafting paradigms, preventing us from drawing a conclusion about the CNTF promigratory effect on this specific cell population. To assess this question, we challenged purified OPCs in various in vitro migration assays. The recording of OPC migration was performed during a time period in line with healthy cell observation, and experiments were performed on purified cells to avoid any indirect effect.

First, we examined p-STAT3, one of the downstream signaling pathways of CNTF in purified OPCs stimulated by CNTF in culture (Fig. 4A, B). We found a significant increase in p-STAT3 immunofluorescence in CNTF-treated OPCs $(p=0.028$; Fig. $4 C$ ). Then, using Boyden chambers, we examined OPC migratory 

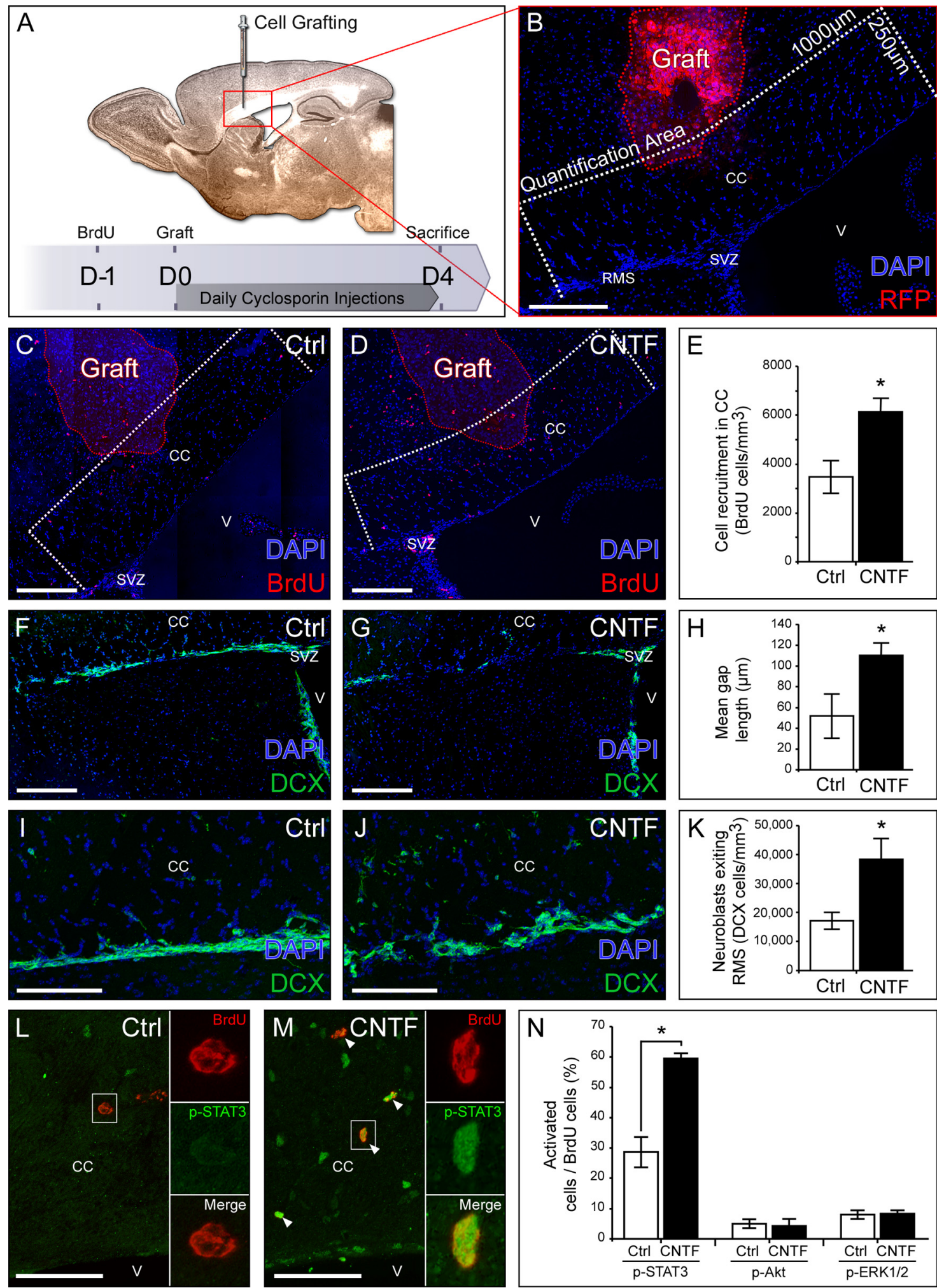

Figure 2. Ectopic CNTF expression controls SVZ-derived cell migration. A, Representation of the experimental design. $B$, Illustration of the graft of mRFP HEK cells secreting CNTF in the CC. SVZ-derived cells recruited in the $C($ were quantified within a $250-\mu \mathrm{m}$-wide by $1000-\mu \mathrm{m}$-long (500 $\mu \mathrm{m}$ on both sides of the graft) area (white dashed line) around the CNTF-secreting cells (red dashed line). Control mice were grafted with mRFP HEK cells secreting no CNTF. C, D, BrdU labeling showing SVZ-derived cells recruited toward the graft of control cells $\left(\boldsymbol{C}\right.$ ) and CNTF-secreting cells (D).E, Quantification of BrdU ${ }^{+}$cells within the CC (quantification area) showing an increase in SVZ-derived cell recruitment toward the ectopic source of CNTF compared with control source. $\boldsymbol{F}, \boldsymbol{G}, \mathrm{DCX}$ labeling showing the architecture of the RMS. $\boldsymbol{H}$, Quantification showing longer RMS interruptions (gaps) in CNTF-secreting HEK-grafted mice. I,J, DCX labeling showing neuronal progenitors exiting the RMS to migrate to the CC. $K$, Quantification of the number of DCX ${ }^{+}$cells present within a 100- $\mu \mathrm{m}$-wide stripe above the RMS. More cells are migrating out of the RMS toward the ectopic source of CNTF compared with control source. $L, M$, BrdU and p-STAT3 labeling showing JAK-STAT3 pathway activation in BrdU ${ }^{+}$cells in theCC. White arrows indicate BrdU ${ }^{+}$p-STAT3 ${ }^{+}$cells.N, Quantification showing an increase of the percentage of p-STAT3 ${ }^{+}$cells relativeto the BrdU ${ }^{+}$ population, in the presence of a source ofCNTF. Note that the percentages of p-Akt ${ }^{+}$and $p$-ERK1/2 ${ }^{+}$cells among BrdU ${ }^{+}$cells are not modulated by the presence of CNTFectopic expression. All pictures are from brain sagittal sections. V, Ventricle. Scale bars: $B-G, L, M, 200 \mu \mathrm{m} ; \boldsymbol{I}, \boldsymbol{J}, 100 \mu \mathrm{m}$. Data are from five control grafted mice and five CNTF-secreting HEK-grafted mice in one experiment. 
Table 2. Cell proliferation and survival after CNTF-secreting HEK cells grafting in corpus callosum

\begin{tabular}{|c|c|c|c|c|}
\hline$\overline{\text { Site }}$ & Cells & Ctrl HEK & CNTF-secreting HEK & $p$ value \\
\hline A: around the graft & $\begin{array}{l}\mathrm{BrdU}^{+} \text {cells } / \mathrm{mm}^{3} \\
\% \mathrm{PH}^{+} / \mathrm{BrdU}^{+} \text {cells } \\
\% \mathrm{Casp}^{+} / \mathrm{BrdU}^{+} \text {cells } \\
\mathrm{PH}^{+} \text {cells } / \mathrm{mm}^{3} \\
\mathrm{Casp}^{+} \text {cells } / \mathrm{mm}^{3}\end{array}$ & $\begin{aligned} 3,462 & \pm 662 \\
3.89 & \pm 1.38 \% \\
2.67 & \pm 2.67 \% \\
2,675 & \pm 372 \\
483 & \pm 126\end{aligned}$ & $\begin{aligned} 6,127 & \pm 573 \\
3.07 & \pm 1.49 \% \\
0.67 & \pm 0.67 \% \\
4,108 & \pm 949 \\
558 & \pm 158\end{aligned}$ & $\begin{array}{l}0.028 \\
0.77 \\
1 \\
0.2 \\
0.91\end{array}$ \\
\hline B: around the graft & 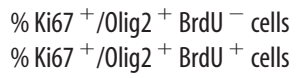 & $\begin{array}{r}2.9 \pm 1.1 \% \\
32.6 \pm 7.8 \%\end{array}$ & $\begin{array}{r}8.4 \pm 2.1 \% \\
33.9 \pm 1.8 \%\end{array}$ & $\begin{array}{l}0.028 \\
0.51\end{array}$ \\
\hline C: SVZ niche & $\mathrm{PH}^{+}{ }^{+}$cells $/ \mathrm{mm}^{3}$ & $64,583.3 \pm 10,958.1$ & $72,916.7 \pm 20,361.2$ & 0.88 \\
\hline
\end{tabular}

For site A, proliferation and survival indexes were determined using PH3 and Casp3 markers, respectively, among BrdU ${ }^{+}$cells around the graft site (see quantification area in Fig. 2B). Overall proliferation and survival indexes were determined by counting the number of PH3 ${ }^{+}$cells $/ \mathrm{mm}^{3}$ and Casp $3^{+}$cells $/ \mathrm{mm}^{3}$ around the graft site. For site B, proliferation of OPCs was determined using Ki67 marker among BrdU ${ }^{+}$Olig2 ${ }^{+}$and BrdU ${ }^{-}$Olig2 ${ }^{+}$cells. For site C, cell proliferation was estimated within the SVZ by counting the number of $\mathrm{PH}^{+}{ }^{+}$cells $/ \mathrm{mm}^{3}$. Data from five control grafted mice and five CNTF-secreting HEK grafted mice in one experiment.

Table 3. SVZ cell populations recruited after CNTF neutralizing antibody and LPC co-injection or CNTF ectopic expression

\begin{tabular}{|c|c|c|c|c|c|c|c|}
\hline Site & Cells & $\lg G$ & anti-CNTF & $p$ value & Control HEK & CNTF-secreting HEK & $p$ value \\
\hline \multirow[t]{4}{*}{$A:$ in the $C C$} & $\%$ Mash1 $^{+} /$BrdU $^{+}$cells & $9.4 \pm 6.2$ & $3.1 \pm 1.0$ & 0.69 & & & \\
\hline & $\% \mathrm{DCX}^{+} / \mathrm{BrdU}^{+}$cells & $73.5 \pm 3.3$ & $85.4 \pm 4.0$ & 0.015 & & & \\
\hline & $\% \mathrm{GFAP}^{+} / \mathrm{BrdU}^{+}$cells & $6.3 \pm 0.6$ & $2.9 \pm 0.8$ & 0.028 & & & \\
\hline & $\% 0$ lig2 ${ }^{+} / \mathrm{BrdU}^{+}$cells & $10.7 \pm 0.8$ & $8.6 \pm 1.4$ & 0.54 & & & \\
\hline
\end{tabular}

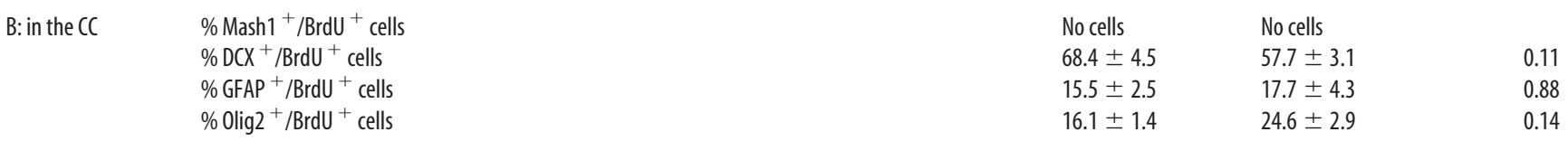

At site A, $4 \mathrm{~d}$ after lesion, BrdU ${ }^{+}$-recruited cells were phenotyped in the CC using Mash1 (SVZ-derived transitory amplifying cells), DCX (neuroblasts), GFAP (astrocytes), and 0lig2 (oligodendrocytes) markers. At site B, following CNTF-secreting HEK cell grafting, BrdU ${ }^{+}$-recruited cells were phenotyped in the CC (see quantification area in Fig. 2B) using Mash1, DCX, GFAP, and 0lig2 markers. Site A, Data are from five lgG-treated mice and five anti-CNTF-injected mice in one experiment. Site B, Data are from five control grafted mice and five CNTF-secreting HEK grafted mice in one experiment.

behavior when exposed to different concentrations of CNTF in the presence of AraC, using PDGF as a positive control (Zhang et al., 2004) (10 ng/ml) (Fig. 4D). The effect of CNTF on OPC migration was quite constant, with a twofold increase in the number of migrating cells for concentrations ranging from 1 to $10 \mathrm{ng} / \mathrm{ml}\left(p=9.8 \times 10^{-4}\right.$ and $p=0.001$, respectively $)$, but the difference was not significant at higher concentrations. $(p=0.15$; Fig. $4 D$ ). In the absence of a CNTF gradient, the migratory effect dropped to control levels ( $100 \pm 13 \%$ in control vs $72 \pm 13 \%$ in CNTF without gradient conditions; $p=0.095)$, which means that CNTF is acting on OPCs as a chemoattractant (Fig. 4D).

Video time-lapse experiments were performed to complete those observations. Aggregates of OPCs (Miyamoto et al., 2008) were embedded into Matrigel in the presence of a source of CNTF or PBS as control. Over the period of recording $(10 \mathrm{~h})$, cells spread out of the aggregate; consequently, we could track them as individual migrating cells (Fig. $4 E, F$ ). We quantified the efficient migration length traveled over the recording period and the mean migration speed using manual tracking of the cells (Fig. $4 G)$. We found that the mean efficient migration length of OPCs was increased by $45 \%$ proximal to the source of CNTF compared with control ( $p=0.029$; Fig. $4 H)$. In the presence of CNTF, the migration was clearly oriented toward the source of the factor $(96 \pm 9 \mu \mathrm{m}$ in CNTF proximal vs $44 \pm 13 \mu \mathrm{m}$ in CNTF distal; $p=0.025$; Fig. $4 F, H)$. This effect was not observed in the control (Fig. 4E,H). The mean migration speed of OPCs was also affected, with an increase of $36 \%$ proximal to the source of CNTF compared with control ( $p=0.028$; Fig. $4 I)$, while mean distal speed remained unchanged ( $p=0.62$; Fig. $4 I$ ). Finally, the tortuosity of the cell trajectory was not influenced by the source of CNTF $(1.88 \pm 0.13$ in proximal control vs $2.47 \pm 0.23$ in proximal CNTF; $p=0.12$ ). Importantly, none of the cells tracked during the time of recording divided or died, which rules out any proliferative or survival aspect and argues in favor of a solely migratory effect. Together, these data indicate that CNTF acts as a chemoattractant on OPCs in vitro and also regulates their motility.

\section{Discussion}

Our analysis shows for the first time that CNTF regulates the migratory behavior of neural progenitors. We have shown using various in vitro paradigms that CNTF controls the directed migration of SVZ neural progenitors and purified OPCs. We also demonstrated that CNTF can directly influence the migration of neural progenitors in vivo and participates by this activity in the mobilization of endogenous progenitor cells in a mouse model of acute demyelination of the CC.

The implication of cytokines from the IL6 family in the control of cell migration in the nervous system has rarely been evaluated. In the mouse, leukemia inhibitory factor (LIF) is prenatally expressed in nasal regions where gonadotropin-releasing hormone $(\mathrm{GnRH})$ neurons originate and start their migration (Magni et al., 2007). In vitro LIF stimulates intrinsic cell motility and directional migration of two cell lines related to $\mathrm{GnRH}$ neurons (Magni et al., 2007). To better characterize CNTF migratory effects on the various cell populations involved in the self-repair process in demyelinated models, we used various in vitro paradigms. Using Boyden chamber and Matrigel assays, we demonstrated a role for CNTF in the regulation of SVZ neural progenitors migrating individually and SVZ neuronal progenitors migrating as chains, respectively. This is in agreement with previous work showing that CNTF-loaded collagen gels promote spinal cord stem cell migration from neonate rat in vitro (Yang et al., 2010). CNTF also enhances the migration speed of neuronal progenitors, which migrate from the dentate gyrus into the granule cell layer in the adult brain (Emsley and Hagg, 2003). However, the authors reported that a single injection above the RMS failed to disturb the cohesive nature of the stream or to attract neuronal progenitors toward the injection site (Emsley and Hagg, 

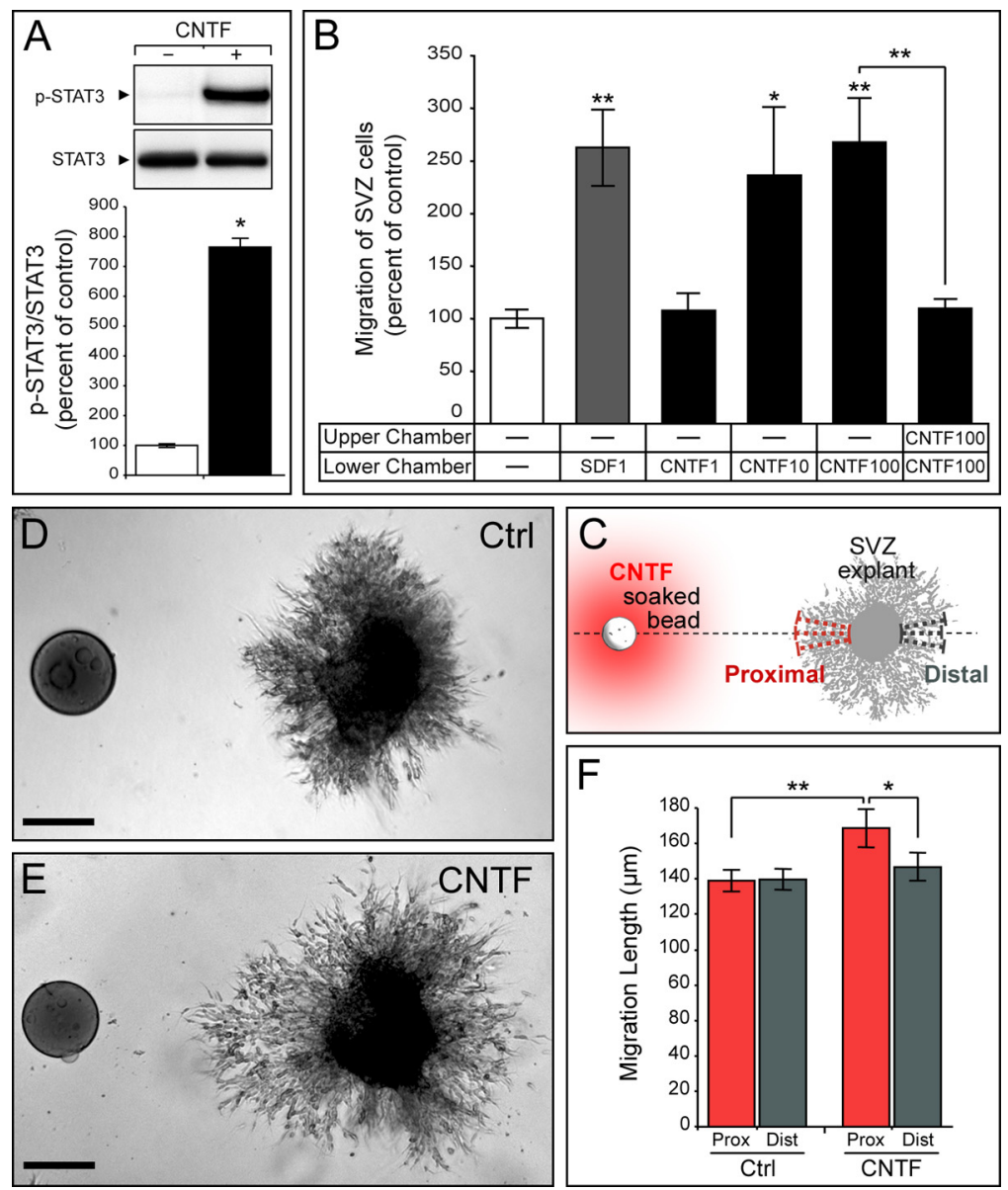

Figure 3. Effect of CNTF on SVZ cell migration in vitro. $\boldsymbol{A}$, Western blot and semiquantitative analysis of STAT3 phosphorylation after the stimulation of in vitro amplified SVZ cells with recombinant CNTF (data from three independent experiments). p-STAT3 expression was normalized to nonphosphorylated STAT3 and expressed as a percentage of control (no stimulation). B, Quantification of SVZ cell migration through chemotaxis chambers (Boyden chambers) (data are from six independent experiments). After cell plating, different growth factors were used in the lower chambers to stimulate SVZ cell migration. SDF1 was used as a positive control. CNTF has the strongest effect at $100 \mathrm{ng} / \mathrm{ml}$. Note that SVZ cell migration is not improved in absence of a gradient (CNTF in both compartments). $\mathbf{C}-\boldsymbol{F}$, SVZ neuronal progenitor migratory behavior was determined using the Matrigel assay. C, Illustration showing SVZ explants cultured in Matrigel in the vicinity of a bead soaked with CNTF or PBS for control. The length of chains formed by cells migrating out of the explant was measured in three independent measures proximally and distally to the bead. $\boldsymbol{D}, \boldsymbol{E}$, Neuronal progenitor migration pattern in the absence $(\boldsymbol{D})$ or presence $(\boldsymbol{E})$ of CNTF. $\boldsymbol{F}$, Quantification of chain length proximal and distal to the source of CNTF (data are from 70 control explants and 30 CNTF explants from six independent experiments). The significant lengthening of proximal chains argues in favor of a chemoattractant effect of CNTF on SVZ neuronal progenitors. Scale bars, $100 \mu \mathrm{m}$.

2003). Our in vivo results are in contrast to this observation, since we have shown that CNTF-expressing cells grafted above the SVZ-RMS stimulated the migration of SVZ-derived cells toward the CC and disturbed the architecture of the rostral migratory stream. This could be due to the dose of CNTF accessible, since we grafted cells constantly secreting CNTF over a $4 \mathrm{~d}$ period, while Emsley and Hagg (2003) injected $1 \mu \mathrm{l}$ of CNTF $(1 \mathrm{mg} / \mathrm{ml})$ in the entire brain volume. Interestingly, in this context, our in vitro data using Boyden chambers clearly show that the effect of CNTF on migratory behavior depends on the dose of cytokine and on the cell type used in the assays.

Numerous factors have been shown to control OPC-directed migration (de Castro and Bribián, 2005). Among them, PDGF, which we used as a positive control, is expressed from developmental stages (Ellison et al., 1996) to adulthood (Stöckli et al., 1991) and was shown to affect OPC-directed migration in vitro (Armstrong et al., 1990; Zhang et al., 2004). Using Boyden cham- bers and video time-lapse analysis, we demonstrated directed OPC migration toward a source of CNTF. We have also observed that purified OPCs respond to CNTF in Boyden chambers. Altogether, our analysis shows that CNTF can act as a chemoattractant for various types of progenitors.

Progenitor migration is an early and essential step in the myelin repair process, which precedes the differentiation of the cells to form myelinating oligodendrocytes. Most of the analyses aiming at addressing the implication of CNTF or other cytokines of its family in myelin repair have been performed in the spinal cord or in models in which quantitative analysis of cell recruitment is not always feasible. Here we have performed a local injection of LPC, which initiates a rapid and focal demyelination of the CC, as a model suitable for quantitative analysis of cell migration (Decker et al., 2002; Cantarella et al., 2008; Courtès et al., 2011). In this model, we have shown that CNTF expression is observed early after lesion induction in the ipsilateral side (Fig. 1A) and more broadly $7 \mathrm{~d}$ after lesion induction in both hemisphere. This result is consistent with previous observations indicating that CNTF is expressed after demyelination in the cuprizone mouse model (Emery et al., 2006; Gudi et al., 2011) and is maintained in the early phase of remyelination (Gudi et al., 2011). This result also indicates that the LPC-induced focal demyelination generates a more general reactivity of the CC probably due to axonal suffering or degeneration. Here we analyzed the recruitment of SVZ-derived progenitors toward the demyelinated CC $4 \mathrm{dpi}$. This is at a time when demyelination is completed and cells derived from the SVZ can be easily identified at the injury site. A key finding in this study is that CNTF participates in the mobilization processes by stimulating SVZ-derived progenitor migration toward the lesioned CC, as demonstrated by a reduction of the number of recruited cells after CNTF-blocking antibody injection. This reduction cannot be attributed to cell survival decrease since cell proliferation and cell death are not significantly modified at the lesion site. Furthermore, we have observed that CNTF-blocking antibody injection increases the percentage of neuronal progenitors and decreases the percentage of astrocytes among mobilized cells in the CC. These results suggest that either CNTF mobilizes a specific cell type from the SVZ or influences cell fate after recruitment in the context of LPC-induced demyelination. This observation is in agreement with previous work indicating that CNTF favors glial cell fate in vitro and in vivo (Bauer et al., 2007).

We then directly created an ectopic source of CNTF in vivo in physiological conditions. We observed a disturbance in the migratory behavior of SVZ-derived progenitors $4 \mathrm{~d}$ after the graft of CNTF-expressing cells in the CC, with a strong increase in the 

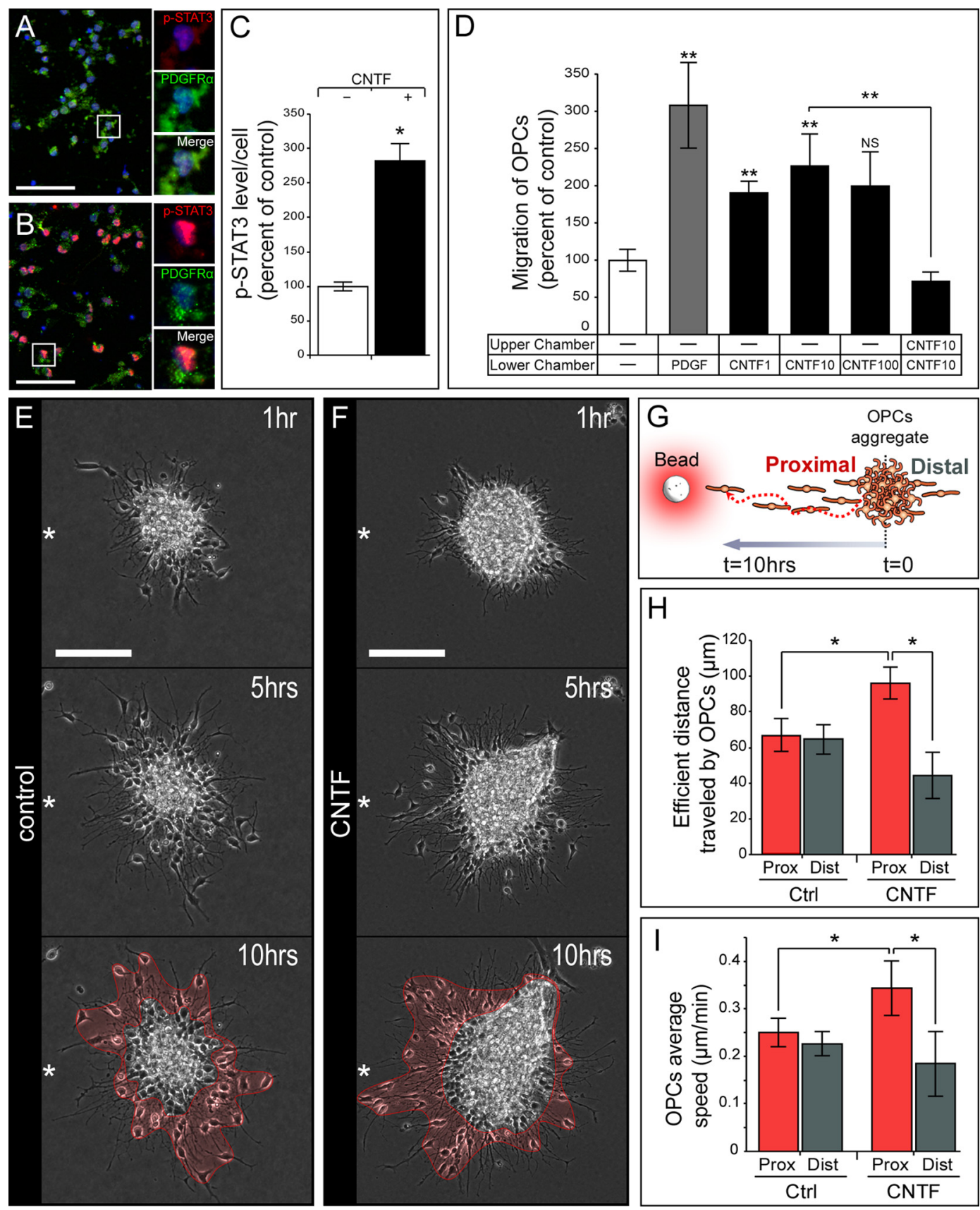

Figure 4. Effect of CNTF on the migratory behavior of purified OPCs in vitro. $\boldsymbol{A}-\boldsymbol{C}$, Increased p-STAT3 (red) expression on purified OPCs (PDGFR $\alpha^{+}$, green) after CNTF exposure was visualized by immunofluorescence and directly quantified on four independent experiments. D, Quantification of purified OPC migration through Boyden chambers (data are from eight independent experiments). PDGF was used as a positive control. CNTF has the strongest effect at $10 \mathrm{ng} / \mathrm{ml}$. Note that OPC migration is not improved in the absence of a gradient. $\boldsymbol{E}-\boldsymbol{I}$, The migratory behavior of OPCS was further determined using video time-lapse analysis on modified aggregation assays. $\boldsymbol{E}, \boldsymbol{F}, \mathrm{OPC}$ migration pattern in the absence $(\boldsymbol{E})$ or presence $(\boldsymbol{F})$ of CNTF. White stars indicate the source's position relative to the explant. Note that OPCs migrated preferentially in the direction of the CNTF source, whereas they were equally distributed in the control condition. G, Illustration showing OPC aggregates cultured in Matrigel in the vicinity of a bead soaked with CNTF or PBS for control. $\boldsymbol{H}$, Quantification of the efficient distance traveled by OPCs proximal and distal to the source of CNTF. The longer cell migration distance proximal to the source of CNTF, compared with proximal control and distal CNTF, argues further in favor of a chemoattractant effect of CNTF on OPCs. I, Quantification of OPC migration speed proximal and distal to the source of CNTF. OPCs migrate faster proximal to the source of CNTF compared with proximal control and distal CNTF OPCs. Data are from three independent experiments. Scale bars: $\boldsymbol{A}, \boldsymbol{B}, 50 \mu \mathrm{m} ; \boldsymbol{E}, \boldsymbol{F}, 100 \mu \mathrm{m}$.

number of SVZ-derived cells within this structure compared with control. These cells responding to CNTF by redistribution in the CC specifically modulate the JAK/STAT3 pathway, suggesting a direct effect of CNTF on these populations. Interestingly, the SVZ-RMS pathway was slightly disorganized, supporting the idea that signals changing the migratory behavior of neural progenitors created a visible disorganization in the RMS. Consequently, derouted ectopic neuronal progenitors were more numerous in the CC in the presence of an ectopic source of CNTF. These data indicate that a CNTF localized source changes the directional migration of SVZ cells and forces these cells to exit the migratory stream and move into the adjacent CC.

CNTF has been shown to increase cell proliferation and decrease cell death of neural progenitors in the SVZ in physiological conditions (Shimazaki et al., 2001; Emsley and Hagg, 2003; Yang et al., 2008). More importantly, many studies have also high- 
lighted the neuroprotective and reparative activities of CNTF in demyelinating pathologies (Linker et al., 2002; Lu et al., 2009). In particular, CNTF has been shown to modulate endogenous progenitor mobilization by modulating neural progenitor proliferation and/or survival (Linker et al., 2002; Lu et al., 2009) in mouse models of demyelination. Here, we have observed a clear and significant proliferation effect of CNTF on parenchymal OPCs. Interestingly, we did not observe significant differences in SVZ cell proliferation and survival in both in vivo models examined. We observed no significant difference in SVZ cell proliferation at the lesion site or in the niche after CNTF blocking antibody injection in the LPC model. These results suggest that CNTF does not regulate SVZ-derived cell proliferation in this model, nor does CNTF ectopic expression in the CC after grafting modify SVZ cell proliferation. This result differs from a previous analysis by Emsley and Hagg (2003), who showed that 9 d after a single CNTF injection, cell proliferation was significantly increased in the niche. Our analysis was performed $4 \mathrm{~d}$ after grafting CNTFexpressing cells, allowing us to visualize migratory effects with no significant increase in proliferation.

Altogether, both in vivo approaches suggest that the modulation of cell mobilization of SVZ cells toward the CC after lesions or after CNTF-secreting cell grafts is not the result of any cell proliferation and/or survival variations or a neuroprotective effect, but relates to a specific effect of CNTF on cell migration.

Growth factors and cytokines are involved in the orchestration of the regenerative process after demyelination in the brain. Here we show for the first time that, besides its trophic effect, CNTF acts as a promigratory factor, acting on SVZ progenitorand OPC-directed cell migration. These results suggest that $\mathrm{CNTF}$, in addition to other cytokines acting on neuroprotection and immune response modulation in neuroinflammatory models such as EAE (Giess et al., 2002; Linker et al., 2008; Lu et al., 2009) could have an additional role in the repair process by stimulating cell-directed migration. This would place these cytokines as major regulators of the regenerative process in inflammatory diseases such as MS.

\section{References}

Adler R, Landa KB, Manthorpe M, Varon S (1979) Cholinergic neuronotrophic factors: intraocular distribution of trophic activity for ciliary neurons. Science 204:1434-1436. CrossRef Medline

Aguirre A, Dupree JL, Mangin JM, Gallo V (2007) A functional role for EGFR signaling in myelination and remyelination. Nat Neurosci 10:9901002. CrossRef Medline

Albrecht PJ, Murtie JC, Ness JK, Redwine JM, Enterline JR, Armstrong RC, Levison SW (2003) Astrocytes produce CNTF during the remyelination phase of viral-induced spinal cord demyelination to stimulate FGF-2 production. Neurobiol Dis 13:89-101. CrossRef Medline

Armstrong RC, Harvath L, Dubois-Dalcq ME (1990) Type 1 astrocytes and oligodendrocyte-type 2 astrocyte glial progenitors migrate toward distinct molecules. J Neurosci Res 27:400-407. CrossRef Medline

Barres BA, Schmid R, Sendnter M, Raff MC (1993) Multiple extracellular signals are required for long-term oligodendrocyte survival. Development 118:283-295. Medline

Barres BA, Burne JF, Holtmann B, Thoenen H, Sendtner M, Raff MC (1996) Ciliary neurotrophic factor enhances the rate of oligodendrocyte generation. Mol Cell Neurosci 8:146-156. CrossRef Medline

Bauer S, Kerr BJ, Patterson PH (2007) The neuropoietic cytokine family in development, plasticity, disease and injury. Nat Rev Neurosci 8:221-232. CrossRef Medline

Boulton TG, Stahl N, Yancopoulos GD (1994) Ciliary neurotrophic factor/ leukemia inhibitory factor/interleukin 6/oncostatin M family of cytokines induces tyrosine phosphorylation of a common set of proteins overlapping those induced by other cytokines and growth factors. J Biol Chem 269:11648-11655. Medline

Cantarella C, Cayre M, Magalon K, Durbec P (2008) Intranasal HB-EGF administration favors adult SVZ cell mobilization to demyelinated lesions in mouse corpus callosum. Dev Neurobiol 68:223-236. CrossRef Medline

Carbajal KS, Schaumburg C, Strieter R, Kane J, Lane TE (2010) Migration of engrafted neural stem cells is mediated by CXCL12 signaling through CXCR4 in a viral model of multiple sclerosis. Proc Natl Acad Sci U S A 107:11068-11073. CrossRef Medline

Chazal G, Durbec P, Jankovski A, Rougon G, Cremer H (2000) Consequences of neural cell adhesion molecule deficiency on cell migration in the rostral migratory stream of the mouse. J Neurosci 20:1446-1457. Medline

Chen Y, Balasubramaniyan V, Peng J, Hurlock EC, Tallquist M, Li J, Lu QR (2007) Isolation and culture of rat and mouse oligodendrocyte precursor cells. Nat Protoc 2:1044-1051. CrossRef Medline

Connor B, Gordon RJ, Jones KS, Maucksch C (2011) Deviating from the well travelled path: precursor cell migration in the pathological adult mammalian brain. J Cell Biochem 112:1467-1474. CrossRef Medline

Courtès S, Vernerey J, Pujadas L, Magalon K, Cremer H, Soriano E, Durbec P, Cayre M (2011) Reelin controls progenitor cell migration in the healthy and pathological adult mouse brain. PLoS One 6:e20430. CrossRef Medline

de Castro F, Bribián A (2005) The molecular orchestra of the migration of oligodendrocyte precursors during development. Brain Res Brain Res Rev 49:227-241. CrossRef Medline

Decker L, Picard-Riera N, Lachapelle F, Baron-Van Evercooren A (2002) Growth factor treatment promotes mobilization of young but not aged adult subventricular zone precursors in response to demyelination. J Neurosci Res 69:763-771. CrossRef Medline

Durbec P, Rougon G (2001) Transplantation of mammalian olfactory progenitors into chick hosts reveals migration and differentiation potentials dependent on cell commitment. Mol Cell Neurosci 17:561-576. CrossRef Medline

Dutta R, McDonough J, Chang A, Swamy L, Siu A, Kidd GJ, Rudick R, Mirnics K, Trapp BD (2007) Activation of the ciliary neurotrophic factor (CNTF) signalling pathway in cortical neurons of multiple sclerosis patients. Brain 130:2566-2576. CrossRef Medline

Dziembowska M, Tham TN, Lau P, Vitry S, Lazarini F, Dubois-Dalcq M (2005) A role for CXCR4 signaling in survival and migration of neural and oligodendrocyte precursors. Glia 50:258-269. CrossRef Medline

Ellison JA, Scully SA, de Vellis J (1996) Evidence for neuronal regulation of oligodendrocyte development: cellular localization of platelet-derived growth factor alpha receptor and A-chain mRNA during cerebral cortex development in the rat. J Neurosci Res 45:28-39. CrossRef Medline

Emery B, Cate HS, Marriott M, Merson T, Binder MD, Snell C, Soo PY, Murray S, Croker B, Zhang JG, Alexander WS, Cooper H, Butzkueven H, Kilpatrick TJ (2006) Suppressor of cytokine signaling 3 limits protection of leukemia inhibitory factor receptor signaling against central demyelination. Proc Natl Acad Sci U S A 103:7859-7864. CrossRef Medline

Emsley JG, Hagg T (2003) Endogenous and exogenous ciliary neurotrophic factor enhances forebrain neurogenesis in adult mice. Exp Neurol 183: 298-310. CrossRef Medline

Franklin RJ, ffrench-Constant C (2008) Remyelination in the CNS: from biology to therapy. Nat Rev Neurosci 9:839-855. CrossRef Medline

Galvão RP, Garcia-Verdugo JM, Alvarez-Buylla A (2008) Brain-derived neurotrophic factor signaling does not stimulate subventricular zone neurogenesis in adult mice and rats. J Neurosci 28:13368-13383. CrossRef Medline

Gensert JM, Goldman JE (1997) Endogenous progenitors remyelinate demyelinated axons in the adult CNS. Neuron 19:197-203. CrossRef Medline

Giess R, Mäurer M, Linker R, Gold R, Warmuth-Metz M, Toyka KV, Sendtner M, Rieckmann P (2002) Association of a null mutation in the CNTF gene with early onset of multiple sclerosis. Arch Neurol 59:407-409. CrossRef Medline

Gonzalez-Perez O, Romero-Rodriguez R, Soriano-Navarro M, GarciaVerdugo JM, Alvarez-Buylla A (2009) Epidermal growth factor induces the progeny of subventricular zone type B cells to migrate and differentiate into oligodendrocytes. Stem Cells 27:2032-2043. CrossRef Medline

Gregg C, Weiss S (2005) CNTF/LIF/gp130 receptor complex signaling maintains a VZ precursor differentiation gradient in the developing ventral forebrain. Development 132:565-578. CrossRef Medline

Gudi V, Škuljec J, Yildiz Ö, Frichert K, Skripuletz T, Moharregh-Khiabani D, Voss E, Wissel K, Wolter S, Stangel M (2011) Spatial and temporal pro- 
files of growth factor expression during CNS demyelination reveal the dynamics of repair priming. PLoS One 6:e22623. CrossRef Medline

Heinrich PC, Behrmann I, Müller-Newen G, Schaper F, Graeve L (1998) Interleukin-6-type cytokine signalling through the gp130/Jak/STAT pathway. Biochem J 334:297-314. Medline

Ichiki T, Jougasaki M, Setoguchi M, Imamura J, Nakashima H, Matsuoka T, Sonoda M, Nakamura K, Minagoe S, Tei C (2008) Cardiotrophin-1 stimulates intercellular adhesion molecule- 1 and monocyte chemoattractant protein-1 in human aortic endothelial cells. Am J Physiol Heart Circ Physiol 294:H750-H763. CrossRef Medline

Jablonska B, Aguirre A, Raymond M, Szabo G, Kitabatake Y, Sailor KA, Ming GL, Song H, Gallo V (2010) Chordin-induced lineage plasticity of adult SVZ neuroblasts after demyelination. Nat Neurosci 13:541-550. CrossRef Medline

Koblar SA, Turnley AM, Classon BJ, Reid KL, Ware CB, Cheema SS, Murphy M, Bartlett PF (1998) Neural precursor differentiation into astrocytes requires signaling through the leukemia inhibitory factor receptor. Proc Natl Acad Sci U S A 95:3178-3181. CrossRef Medline

Linker RA, Mäurer M, Gaupp S, Martini R, Holtmann B, Giess R, Rieckmann P, Lassmann H, Toyka KV, Sendtner M, Gold R (2002) CNTF is a major protective factor in demyelinating CNS disease: a neurotrophic cytokine as modulator in neuroinflammation. Nat Med 8:620-624. CrossRef Medline

Linker RA, Kruse N, Israel S, Wei T, Seubert S, Hombach A, Holtmann B, Luhder F, Ransohoff RM, Sendtner M, Gold R (2008) Leukemia inhibitory factor deficiency modulates the immune response and limits autoimmune demyelination: a new role for neurotrophic cytokines in neuroinflammation. J Immunol 180:2204-2213. Medline

Lu Z, Hu X, Zhu C, Wang D, Zheng X, Liu Q (2009) Overexpression of CNTF in Mesenchymal Stem Cells reduces demyelination and induces clinical recovery in experimental autoimmune encephalomyelitis mice. J Neuroimmunol 206:58-69. CrossRef Medline

Magalon K, Cantarella C, Monti G, Cayre M, Durbec P (2007) Enriched environment promotes adult neural progenitor cell mobilization in mouse demyelination models. Eur J Neurosci 25:761-771. CrossRef Medline

Magni P, Dozio E, Ruscica M, Watanobe H, Cariboni A, Zaninetti R, Motta M, Maggi R (2007) Leukemia inhibitory factor induces the chemomigration of immortalized gonadotropin-releasing hormone neurons through the independent activation of the Janus kinase/signal transducer and activator of transcription 3, mitogen-activated protein kinase/extracellularly regulated kinase $1 / 2$, and phosphatidylinositol 3-kinase/Akt signaling pathways. Mol Endocrinol 21:1163-1174. CrossRef Medline

Miyamoto Y, Yamauchi J, Tanoue A (2008) Cdk5 phosphorylation of WAVE2 regulates oligodendrocyte precursor cell migration through nonreceptor tyrosine kinase Fyn. J Neurosci 28:8326-8337. CrossRef Medline
Nait-Oumesmar B, Decker L, Lachapelle F, Avellana-Adalid V, Bachelin C, Baron-Van Evercooren A (1999) Progenitor cells of the adult mouse subventricular zone proliferate, migrate and differentiate into oligodendrocytes after demyelination. Eur J Neurosci 11:4357-4366. CrossRef Medline

Sendtner M, Carroll P, Holtmann B, Hughes RA, Thoenen H (1994) Ciliary neurotrophic factor. J Neurobiol 25:1436-1453. CrossRef Medline

Shimazaki T, Shingo T, Weiss S (2001) The ciliary neurotrophic factor/ leukemia inhibitory factor/gp130 receptor complex operates in the maintenance of mammalian forebrain neural stem cells. J Neurosci 21:7642-7653. Medline

Sriram K, Benkovic SA, Hebert MA, Miller DB, O’Callaghan JP (2004) Induction of gp130-related cytokines and activation of JAK2/STAT3 pathway in astrocytes precedes up-regulation of glial fibrillary acidic protein in the 1-methyl-4-phenyl-1,2,3,6-tetrahydropyridine model of neurodegeneration: key signaling pathway for astrogliosis in vivo? J Biol Chem 279: 19936-19947. CrossRef Medline

Stankoff B, Aigrot MS, Noël F, Wattilliaux A, Zalc B, Lubetzki C (2002) Ciliary neurotrophic factor (CNTF) enhances myelin formation: a novel role for CNTF and CNTF-related molecules. J Neurosci 22:9221-9227. Medline

Stöckli KA, Lillien LE, Näher-Noé M, Breitfeld G, Hughes RA, Raff MC, Thoenen H, Sendtner M (1991) Regional distribution, developmental changes, and cellular localization of CNTF-mRNA and protein in the rat brain. J Cell Biol 115:447-459. CrossRef Medline

Wichterle H, Garcia-Verdugo JM, Alvarez-Buylla A (1997) Direct evidence for homotypic, glia-independent neuronal migration. Neuron 18:779-791. CrossRef Medline

Williams A, Piaton G, Aigrot MS, Belhadi A, Théaudin M, Petermann F, Thomas JL, Zalc B, Lubetzki C (2007) Semaphorin 3A and 3F: key players in myelin repair in multiple sclerosis? Brain 130:2554-2565. CrossRef Medline

Xu JJ, Chen EY, Lu CL, He C (2009) Recombinant ciliary neurotrophic factor promotes nerve regeneration and induces gene expression in silicon tube-bridged transected sciatic nerves in adult rats. J Clin Neurosci 16:812-817. CrossRef Medline

Yang P, Arnold SA, Habas A, Hetman M, Hagg T (2008) Ciliary neurotrophic factor mediates dopamine D2 receptor-induced CNS neurogenesis in adult mice. J Neurosci 28:2231-2241. CrossRef Medline

Yang Z, Qiao H, Li X (2010) Effects of the CNTF-collagen gel-controlled delivery system on rat neural stem/progenitor cells behavior. Sci China Life Sci 53:504-510. CrossRef Medline

Zhang H, Vutskits L, Calaora V, Durbec P, Kiss JZ (2004) A role for the polysialic acid-neural cell adhesion molecule in PDGF-induced chemotaxis of oligodendrocyte precursor cells. J Cell Sci 117:93-103. CrossRef Medline 